RADOVI

Zavoda za znanstveni rad HAZU Varaždin

KARMEN LEVANIĆ

Državni arhiv u Varaždinu

klevanic@dav.hr
UDK 930.253: 929Rac, K. Izvorni znanstveni članak Original Scientific Paper

Primljeno: 03. 04. 2017.

Prihvaćeno: 26. 06. 2017.

DOI: http://doi.org/10.21857/y6zolb37pm

\title{
KOLOMAN RAC U ARHIVSKIM DOKUMENTIMA
}

Ovaj rad nastoji obogatiti šture biografske podatke o Kolomanu Racu istraživanjem arhivskih dokumenata koji se čuvaju u Državnim arhivima u Varaždinu, Zagrebu i Gospiću. Autorica je krenula od osnovnih biografskih odrednica navedenih u kratkom enciklopedijskom zapisu on-line izdanje Hrvatske enciklopedije Leksikografskog zavoda Miroslav Krleža i pronašla brojne dokumente koji proširuju spoznaje o osobnom i profesionalnom životu Kolomana Raca od rođenja do smrti.

Koloman Rac je uz Tomislava Maretića najplodniji hrvatski prevoditelj s klasičnih jezika čime si je osigurao mjesto u svakoj hrvatskoj općoj enciklopediji. On-line izdanje Hrvatske enciklopedije Leksikografskog zavoda Miroslav Krleža ${ }^{1}$ donosi o njemu natuknicu od $2 / 3$ kartice teksta, $\mathrm{u}$ kojoj se navode datumi i mjesta rođenja $\mathrm{i}$ smrti te gdje je i što radio, dok najveći dio otpada na popis njegovih djela i prijevoda. Ti su osnovni podaci bili putokaz za traženje arhivskih dokumenata koji bi sadržavali više podataka o njegovom životu i radu. Njegov se život odvijao na tri lokacije - $u$ Varaždinu, Gospiću i Zagrebu, pa je upravo arhivsko gradivo iz Državnih arhiva u tim gradovima i Hrvatskog državnog arhiva bilo predmetom istraživanja.

Koloman Rac rodio se u Varaždinu 19. rujna 1863. Takvi su se podaci u to doba bilježili u crkvenim maticama rođenih, vjenčanih i umrlih koje se danas najvećim dijelom čuvaju u državnim arhivima. Tako se i zapis rođenja Kolomana Raca nalazi u matici rođenih župe Sv. Nikole u Varaždinu². Upisan je kao Koloman Frederik Rac, zakoniti sin supružnika Maksimilijana Raca i Katarine rođ. Miok, koji su u to vrijeme živjeli na adresi Varaždin 33. Danas je to Kukuljevićeva $7^{3}$, uglovnica na

1 „Rac, Koloman“, on-line izdanje Hrvatske enciklopedije Leksikografskog zavoda Miroslav Krleža. www.enciklopedija.hr/natuknica.aspx?id=51361 (podaci preuzeti u studenom 2016.).

2 HR-DAVŽ-543 Matične knjige rimokatoličkih župa, Župa sv. Nikole u Varaždinu, Matična knjiga rođenih 1858.-1868.

3 Prema Katastarskom planu grada Varaždina Antuna Kiesswettera iz 1860.g., koji se čuva u Gradskom muzeju Varaždin, inv. br. 3392. 


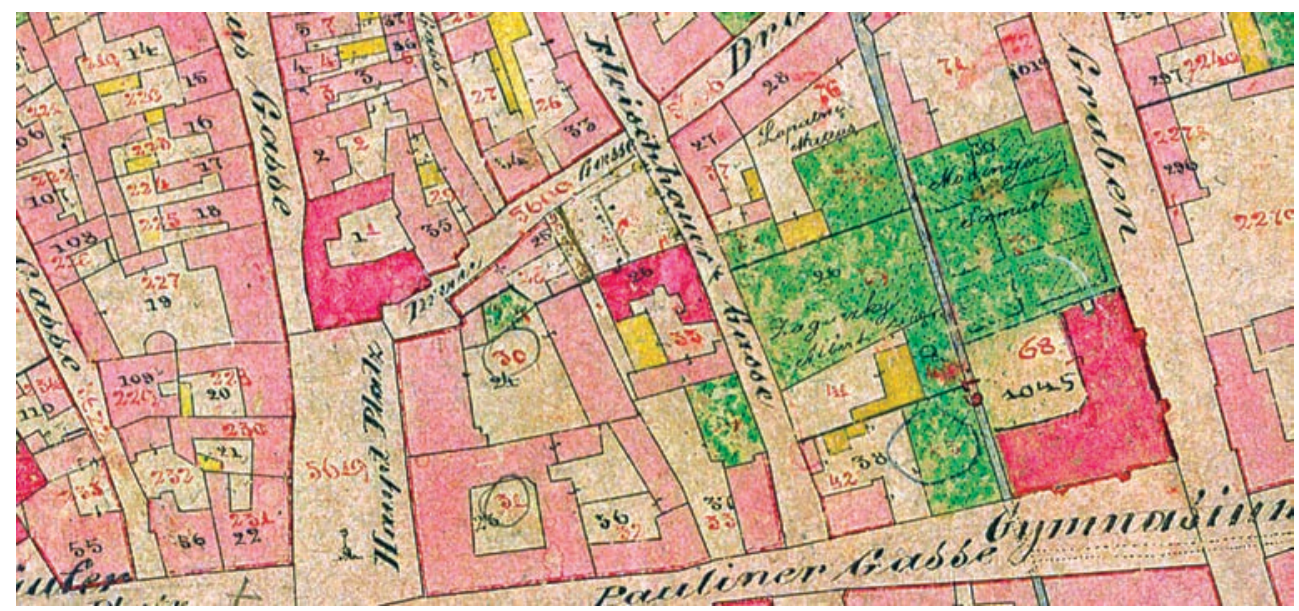

Slika 1. Katastarski plan grada Varaždina Antuna Kiesswettera iz 1860.

(Gradski muzej Varaždin, inv. br. 3392)

raskršću Kukuljevićeve i Šenoine ulice (nekadašnje Dravske i Mesničke ulice). Krsni su mu kumovi bili trgovac Frederik (Miroslav) Pečornik i supruga Terezija (živjeli su na adresi Varaždin 32, današnja Šenoina 8). Koloman je bio treće dijete u obitelji. Prvo je dijete bio sin Julije Adolf (rođen 11. travnja 1860. i umro toga istog dana), a drugo Frederik Ludovik, odnosno Miroslav Ljudevit (rođen 7. kolovoza 1861.). Pregledom matične knjige rođenih do 30. rujna 1868. više nije pronađen ni jedan upis rođenja, tako da se može pretpostaviti da Maksimilijan i Katarina više nisu imali djece. Više podataka o njima (imena roditelja i starost u vrijeme sklapanja braka, odakle se može izračunati godina rođenja) pružila bi matična knjiga vjenčanih. Nažalost, matična knjiga vjenčanih župe sv. Nikola za razdoblje od 1858.1877. nedostaje, a oni su se najvjerojatnije vjenčali 1859. godine.

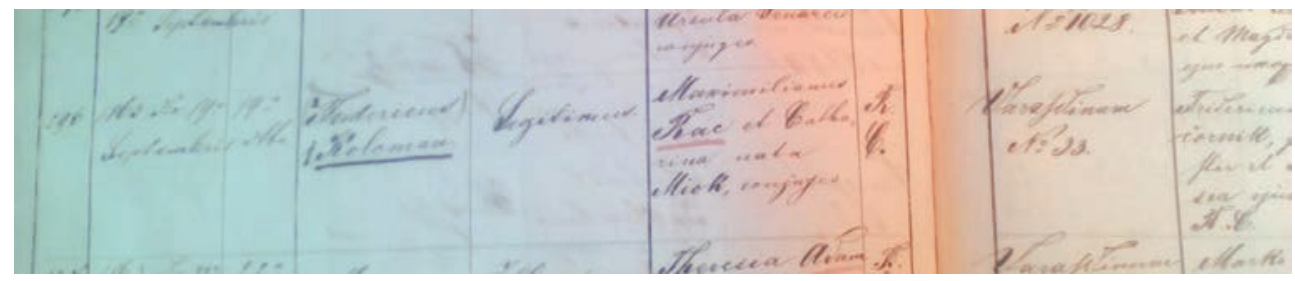

Slika 2. HR-DAVŽ-543 Matične knjige rimokatoličkih župa, Župa sv. Nikole u Varaždinu, Matična knjiga rođenih 1858.-1868. 
Prema postignutom obrazovanju može se zaključiti da je Koloman Rac pohađao gimnaziju. U Državnom arhivu u Varaždinu čuva se fond Gimnazija Varaždin, pa se pristupilo pretraživanju gradiva toga fonda da se pronađu novi podaci o Kolomanu Racu. Pregledane su serije Glavni katalozi (knjige koje sadrže popis svih učenika po razredima s njihovim uspjehom iz pojedinih predmeta) i Zapisnici ispita zrelosti ${ }^{4}$. Prema zapisima iz kataloga Koloman Rac krenuo je u prvi razred gimnazije školske godine 1874/75. s 11 godina, a redovno je završio 1881/82. s 18 godina. Kroz glavne kataloge također možemo pratiti njegov uspjeh i ponašanje. Od osobnih podataka navodi se da mu je otac bio Maksimilijan ili Makso Rac, po zanimanju krojač, i da su stanovali u Sjemenišnoj ulici, kućni broj 76 (prema Kiesswetterovom planu iz 1860.5 kuća se nalazila na mjestu gdje se danas nalazi Hotel Park, Jurja Habdelića 6). Bio je oslobođen školarine, a od 6. prosinca 1877. uživao je potporu iz zaklade Kreutz ${ }^{6}$ u iznosu od 79 forinti i 60 novčića. Kroz svih osam godina bio je odličan đak uzornoga ponašanja i „neumorne“ marljivosti. Bio je iznimno dobra zdravlja - tijekom cijeloga školovanja izostao je svega 13 školskih sati u drugome polugodištu osmoga razreda zbog bolesti. U školi je imao sljedeće predmete: vjeronauk, latinski, grčki (od 3. razreda), njemački, hrvatski (,ilirski“) jezik, povijest („,dogodovštinu“) i zemljopis, prirodne znanosti („naravopis“) i crtanje (,risanje“). Uz to, dvije je godine imao krasnopis (u prva dva razreda), geometriju (u 3. i 4. razredu), talijanski jezik (u 6. i 7. razredu) i uvod u filozofiju, odnosno "mudroslovnu propedeutiku“ (u 7. i 8. razredu). Ocjenjivao se i vanjski oblik pismenih radnji, koji je kroz svih osam godina ocijenjen kao lijep. Krenuo je u gimnaziju sa željom da postane učitelj, kako je zapisano u rubrici „Buduće zvanje“" filolog${ }^{8}$. Kasnije će u životu uspješno objediniti i ostvariti obje svoje mladenačke želje. Ako se gledaju ocjene, grčki jezik mu je išao bolje od latinskog, osobito su ga zanimali povijest, zemljopis i prirodoslovlje, a lijepo je i crtao. Iz talijanskoga jezika i mudroslovne propedeutike u sva je četiri polugodišta imao odličnu ocjenu. Jedino mu glazba baš nije išla - jedno polugodište koliko je imao taj predmet, ocjena mu je bila dovoljan. Iz navedenih podataka u Glavnim katalozima može se zaključiti da je već kao gimnazijalac bio marljiv, uredan i savjestan te da je imao dobre radne navike.

\footnotetext{
HR-DAVŽ-249 Gimnazija Varaždin, Glavni katalozi 1774/75.-1881/82. i Zapisnici ispita zrelosti 1866/67.-1885/86.

5 V. bilješku 3.

6 O zakladi Kreutz vidi: Vida PAVLIČEK: „Varaždinske gradske zaklade krajem 19. i početkom 20. stoljeća", Hrvatska akademija znanosti i umjetnosti, Radovi Zavoda za znanstveni rad Varaždin, 6-7/1994, 123. - 145. i Ljubica RADOVIĆ: „Zaklade, potpore i donacije gimnaziji Varaždinskoj“, Hrvatska akademija znanosti i umjetnosti, Radovi Zavoda za znanstveni rad Varaždin, 10-11/1998, 157. - 180.

7 HR-DAVŽ-249 Gimnazija Varaždin, Glavni katalog 1774/75.

8 HR-DAVŽ-249 Gimnazija Varaždin, Zapisnici ispita zrelosti 1866/67.-1885/86.
} 


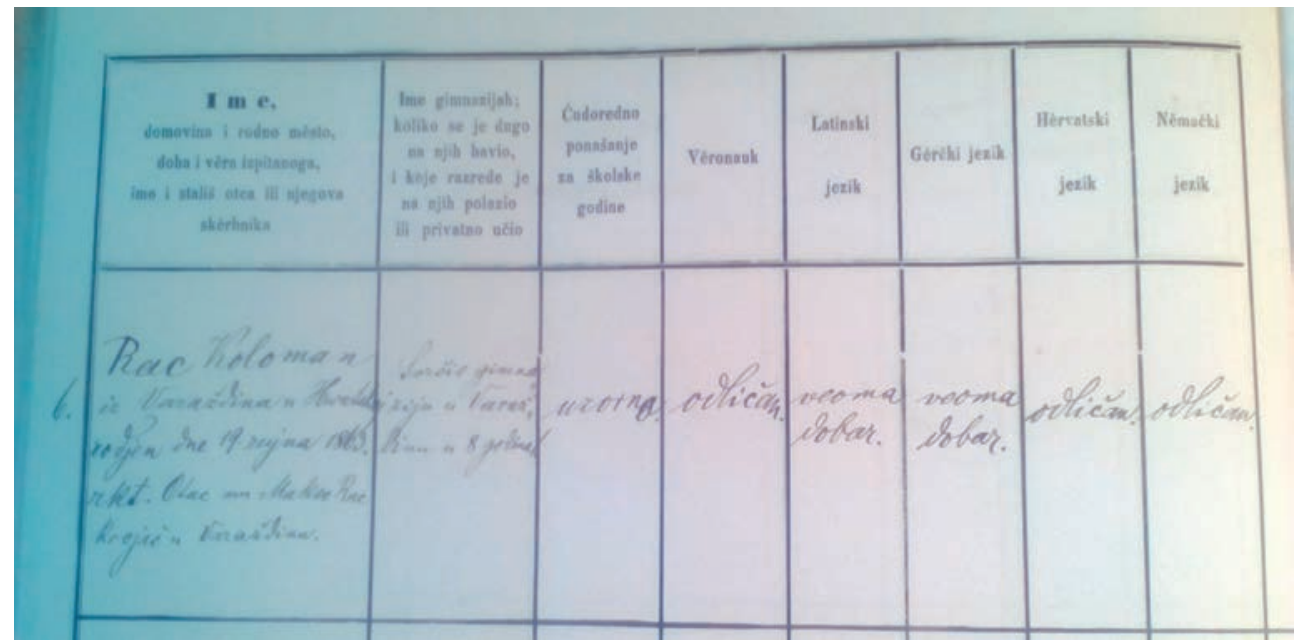

Slika 3. HR-DAVŽ-249 Gimnazija Varaždin, Zapisnici ispita zrelosti 1866/67.-1885/86., lijeva strana

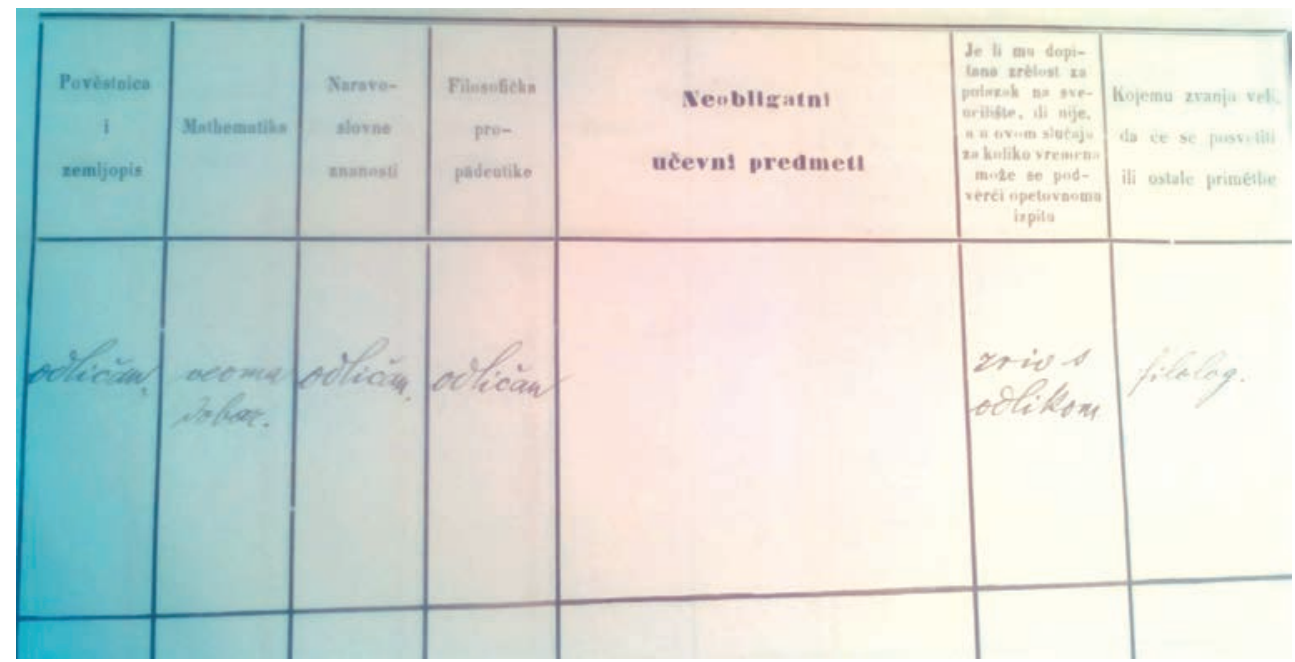

Slika 4. HR-DAVŽ-249 Gimnazija Varaždin, Zapisnici ispita zrelosti 1866/67.-1885/86., desna strana

Poslije završenog gimnazijskog školovanja Koloman Rac odlazi u Zagreb. Prema podacima iz enciklopedijske natuknice radio je na Donjogradskoj gimnaziji. Gradivo nastalo djelovanjem te ustanove čuva se u Državnom arhivu u Zagrebu u fondu II. klasična gimnazija u Zagrebu, u okviru kojeg se nalazi knjiga Matica i sposobnik 


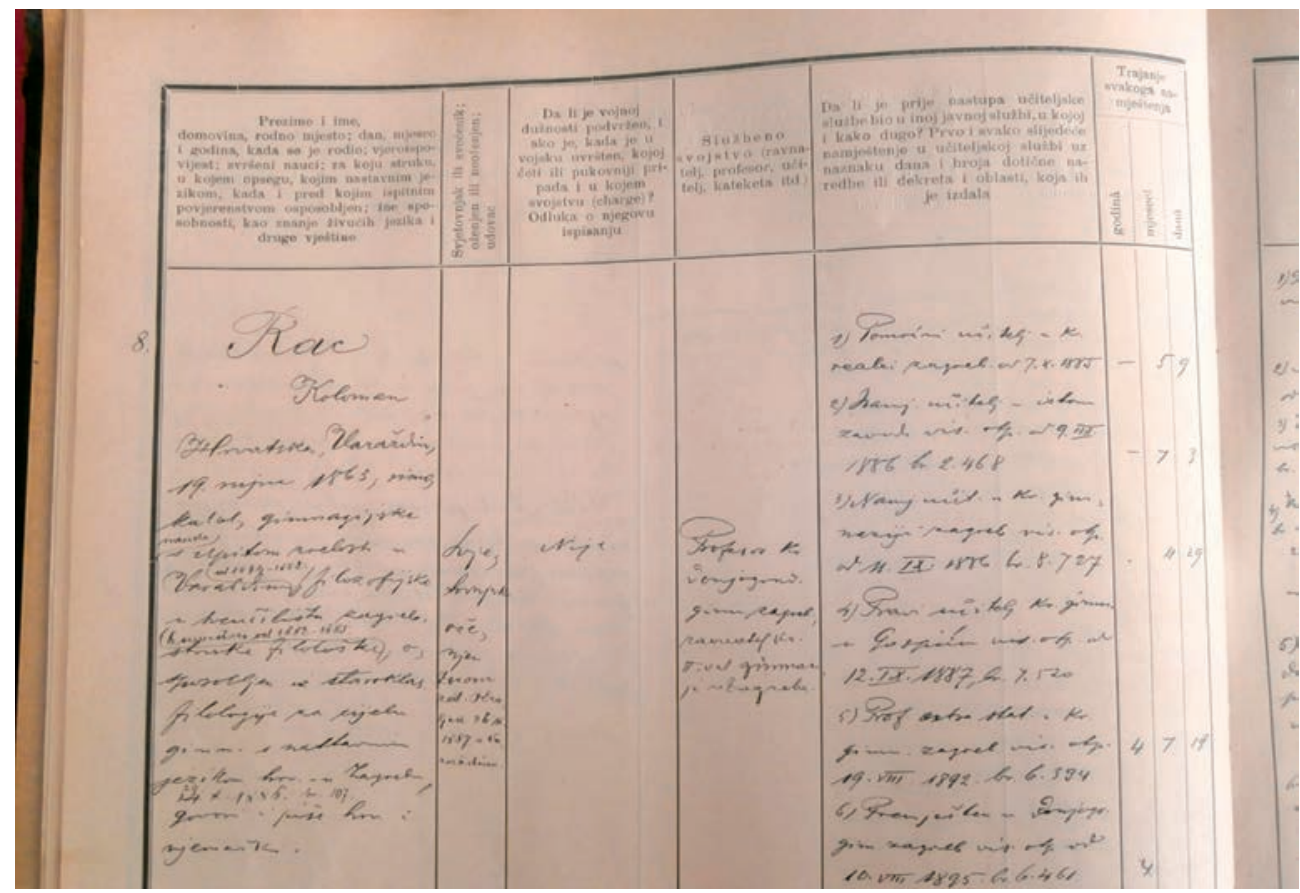

Slika 5. HD-DAZG-103 II. klasična gimnazija u Zagrebu, br. 25270, Matica i sposobnik za učitelje, lijeva strana.

za učitelje. ${ }^{9}$ Ta je knjiga najopsežniji i najpodrobniji izvor za pregled školovanja i radnoga vijeka Kolomana Raca. U prvoj rubrici su njegovi osobni podaci i podaci o školovanju i stručnoj osposobljenosti, u drugoj je li svećenik ili svjetovnjak i njegovo bračno stanje, u trećoj podaci o vojnoj obvezi, a u četvrtoj njegovo službeno svojstvo. U petoj su rubrici popisana sva njegova radna mjesta s brojem dokumenta o imenovanju, a u šestoj trajanje svakoga namještenja. Zatim slijedi rubrika s podacima o plaći i doplatcima, a nakon nje rubrika u koju su se upisivale potpore, drugi poslovi i književni rad. Ta je rubrika posebno zanimljiva jer su tu pobrojana njegova književna i prevodilačka djela. Na kraju je rubrika Opaske s podacima o priznanjima, odlikovanjima, opomenama i sl. Prema zapisu iz te knjige, Koloman Rac je nakon završene gimnazije krenuo u Zagreb na studij na Filozofski fakultet, gdje je odslušao šest semestara (od 1882.-1885.) iz područja filologije. Po završetku studija već 7 . listopada 1885. zaposlio se kao pomoćni učitelj u Kraljevskoj realnoj gimnaziji u Zagrebu, a od 9. ožujka 1886. tamo radi kao namjesni učitelj. Sljedeće školske

9 HR-DAZG-103 II. klasična gimnazija u Zagrebu, br. 25270, Matica i sposobnik za učitelje. 


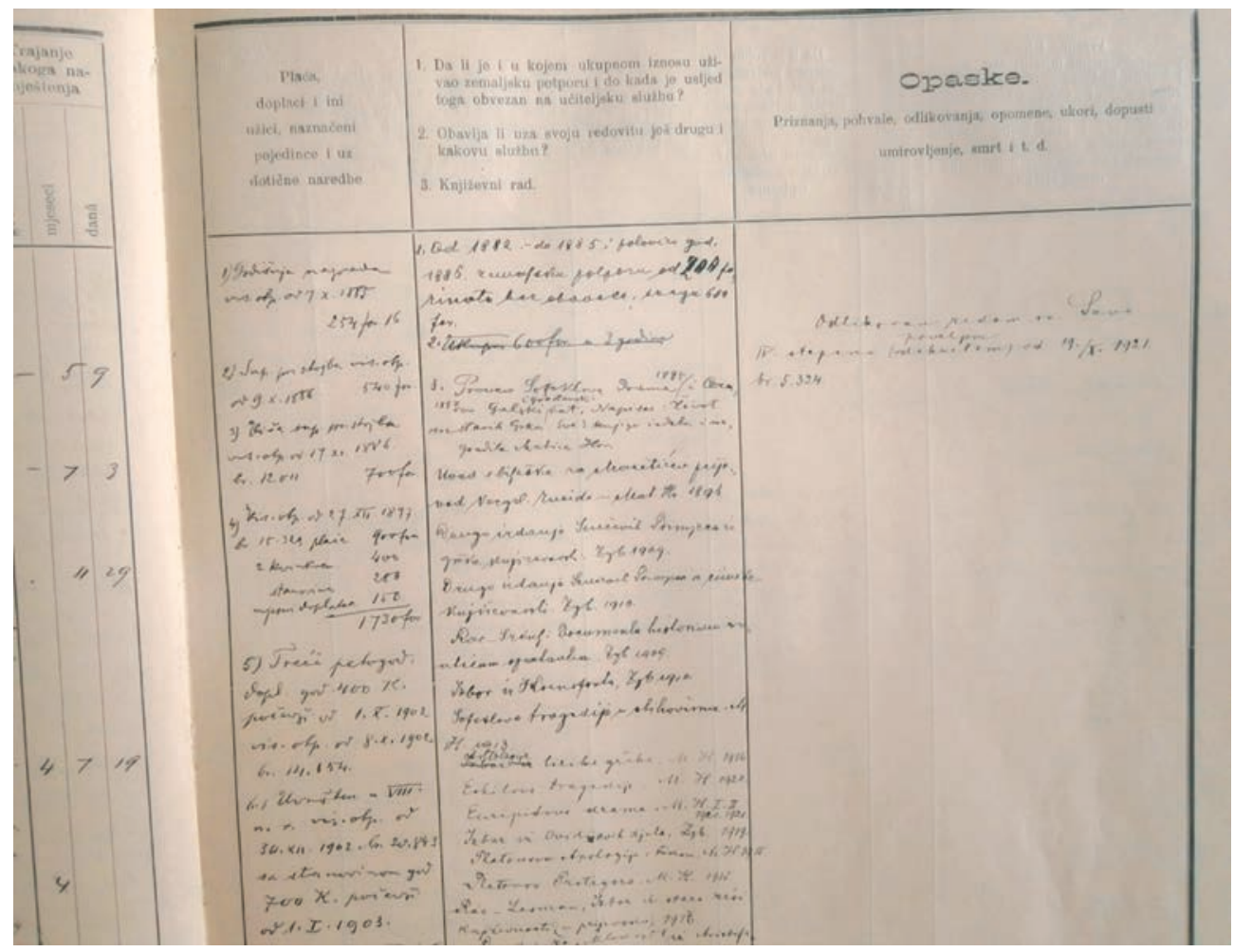

Slika 6. HD-DAZG-103 II. klasična gimnazija u Zagrebu, br. 25270, Matica i sposobnik za učitelje, desna strana.

godine, od rujna 1886. počinje raditi na Kraljevskoj klasičnoj gimnaziji u Zagrebu, također kao namjesni učitelj. U listopadu te iste godine položio je ispit iz klasične filologije za višu gimnaziju i dobio svjedodžbu da je osposobljen iz staroklasične filologije za cijelu gimnazijsku nastavu s hrvatskim kao nastavnim jezikom. ${ }^{10} \mathrm{I} u$ klasičnoj gimnaziji proveo je samo jednu školsku godinu jer već u rujnu 1887. dobiva premještaj na Kraljevsku gimnaziju u Gospiću na mjesto pravoga učitelja.

Prije odlaska u Gospić vjenčao se u Varaždinu 29. rujna 1887. sa Zorom Kraljek. ${ }^{11}$ Punim imenom Aurora (Zorica) Julijana rođena je 2. travnja 1865. kao zakonita kći

10 HR-HDA-502 Ispitna komisija za polaganje stručnih ispita za zvanje profesora srednjih škola Filozofskog fakulteta u Zagrebu, 3 Materijali s ispita - dosje Kolomana Raca.

11 HR-DAVŽ-543 Matične knjige rimokatoličkih župa, Župa sv. Nikole u Varaždinu, Matična knjiga vjenčanih 1878.-1898. 
postolara Ignaca Kraljeka i supruge Barbare rođ. Črnila i krštena u župi Sv. Vida. ${ }^{12} \mathrm{U}$ doba sklapanja braka on je imao 24 godine, a ona 22 i to im je bio prvi brak. Njihovi su roditelji tada još bili živi. Prema bilješci u navedenoj matičnoj knjizi rođenih Zora Kraljek umrla je u Zagrebu 22. siječnja 1952. u 87. godini.

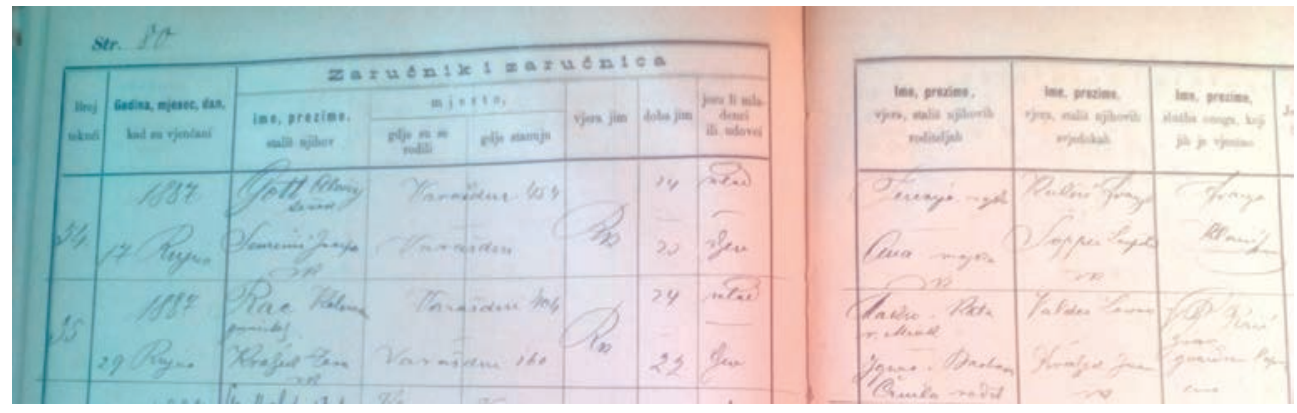

Slika 7. HR-DAVŽ-543 Matične knjige rimokatoličkih župa, Župa sv. Nikole u Varaždinu, Matična knjiga vjenčanih 1878.-1898.

Malo se toga može doznati o životu Kolomana Raca u Gospiću, međutim, njegov boravak ondje ipak je ostavio traga u arhivskim dokumentima, u gradivu Kraljevske velike gimnazije u Gospiću ${ }^{13}$ i matičnim knjigama rođenih i umrlih. ${ }^{14}$ U Glavnom imeniku Kraljevske velike gimnazije za školsku godinu 1889/90. navedeno je da je Koloman Rac nadstojnik drugoga razreda i da podučava latinski jezik u drugom i sedmom razredu, a grčki u trećem. U "Zapisniku ob izpitih zrelosti“, točnije u Bilješci Zapisnika, nalaze se njegovi potpisi za školske godine 1887/88., 1888/89. i 1890/91., što znači da je prisustvovao završnim ispitima. O njegovom obiteljskom životu govore matične knjige rođenih koje pokazuju da je i na tom području bio vrlo produktivan. U pet godina koliko su on i njegova supruga boravili u Gospiću, rodilo im se četvoro djece. 16. lipnja 1888. rodila se prva kći Emilija, koja je umrla sa svega 3 mjeseca 16. rujna 1888. Zatim se 11. svibnja 1889. rodila druga kći Ružica. U matičnu knjigu rođenih dana 18. kolovoza 1890. upisan je Stanislav, zakoniti. Radi se o velikoj pogrešci matičara jer se zapravo rodila kći Stanka, što se vidi iz Imenika zavičajnika grada Zagreba i nadgrobnog spomenika. Konačno se 3. ožujka 1892. rodila kći Helena (Jelena).

\footnotetext{
12 HR-DAVŽ-543 Matične knjige rimokatoličkih župa, Župa sv. Vida u Varaždinu, Matična knjiga rođenih 1860.-1877.

13 HR-DAGS-117 Gimnazija Nikola Tesla Gospić.

14 HR-DAGS-109 Zbirka matičnih knjiga 1878.-1942.
} 


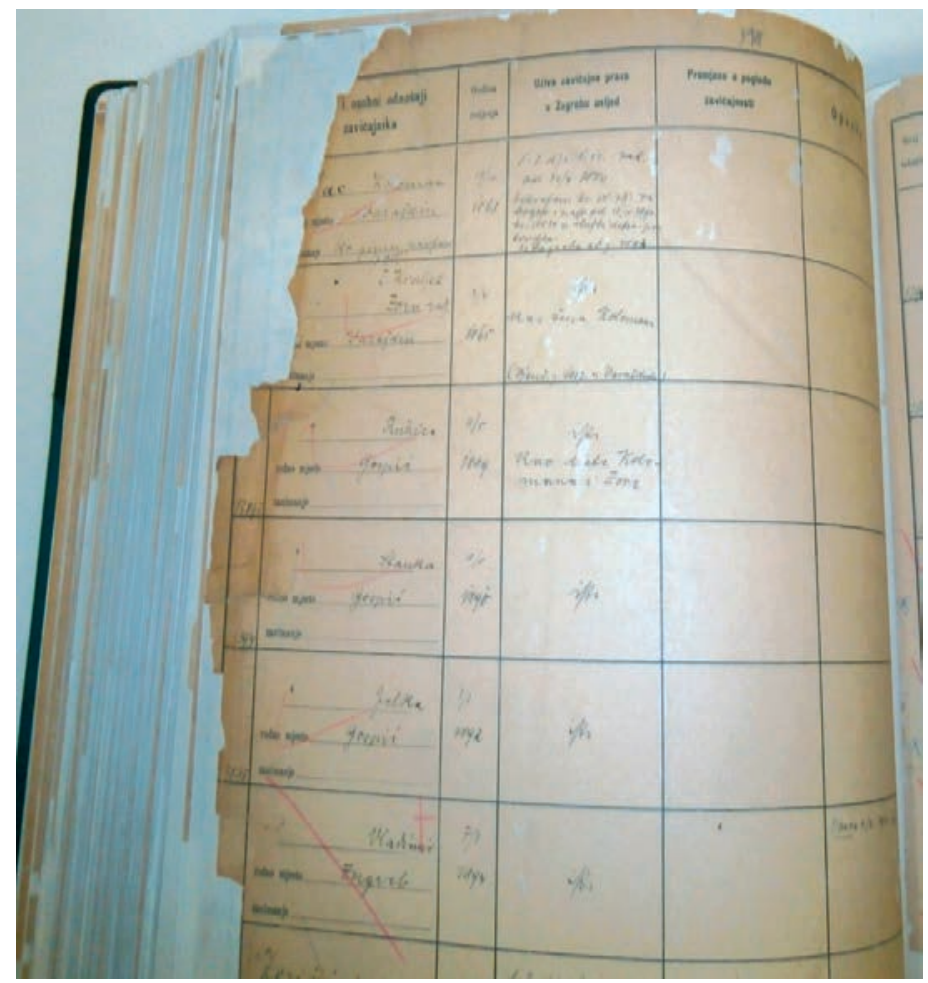

Slika 8. HR-DAZG-24 Gradsko poglavarstvo Zagreb, Politički odsjek, POLIT4, Imenik zavičajnika grada Zagreba.

1892. Koloman Rac dobiva premještaj u Zagreb na Kraljevsku gimnaziju kao izvanredni profesor i obitelj se seli u Zagreb. Tu im se rodilo posljednje dijete, sin Vladimir, rođen 7. ožujka $1894 .{ }^{15}$ a umro 9. veljače 1914. s nepunih dvadeset godina kao mladi pravnik. ${ }^{16}$ Ostala su djeca nadživjela oca i doživjela pristojnu starost te su također pokopana u obiteljskoj grobnici Racovih. Ružica je umrla je 21. kolovoza 1951. sa 62 godine, Stanka, koja je radila kao činovnica u Prvoj hrvatskoj štedionici, ${ }^{17}$ 9. travnja 1979. s 89 godina, a Helena udana Timet 31. kolovoza 1967. sa 75 godina. ${ }^{18}$

\footnotetext{
15 HR-DAZG-24 Gradsko poglavarstvo Zagreb, Politički odsjek, POLIT4, Imenik zavičajnika grada Zagreba.

16 HR-DAZG-24 Gradsko poglavarstvo Zagreb, Opće skupno groblje grada Zagreba na Mirogoju, MIR 42 Grobne knjige groblja Mirogoj, I. razred, grobno polje 11A, br. groba 131.

17 Podatak dobiven ljubaznošću gospođe Zvjezdane Timet, praunuke Kolomana Raca. Na nadgrobnom je spomeniku pogrešno upisano da je Ružica radila u Štedionici.

18 Podaci su preuzeti s fotografije nadgrobnog spomenika obitelji Rac koja se može vidjeti na adresi: https://billiongraves.com/grave/Koloman-Rac/18203563\#/ i Tražilice pokojnika Gradskih groblja Zagreb (http://www.gradskagroblja.hr/default.aspx?id=382) u srpnju 2017.
} 
Prema dostupnim podacima iz Grobne knjige i Mrtvozorničkog registra obitelj Rac je u vrijeme Vladimirove smrti stanovala na adresi Mažuranićev trg $15,{ }^{19}$ a u doba Kolomanove smrti na Marulićevom trgu 10.20

10. kolovoza 1895. Koloman Rac prelazi na Kraljevsku donjogradsku veliku gimnaziju u Zagrebu. To je bila nova gimnazija osnovana odlukom Odjela za bogoštovlje i nastavu Zemaljske vlade 1895. zbog sve većeg broja učenika koje postojeća Kraljevska velika gimnazija u Zagrebu nije mogla prihvatiti. Škola je bila smještena u novoizgrađenu zgradu na današnjem Rooseveltovom trgu (današnji Muzej Mimara) i u prvoj školskoj godini otvorena su četiri niža razreda s preko 400 upisanih učenika. 1914. škola je privremeno preseljena zbog vojnih potreba tako da se nastava odvijala na različitim lokacijama sve do 1918. kad se vraća u vlastitu zgradu. 1921. odlukom Odjeljenja za prosvjetu i vjeru mijenja naziv u Kraljevska II. velika gimnazija u Zagrebu, 1925. postaje Druga državna gimnazija u Zagrebu, a Zakonom o srednjim školama iz 1929. mijenja naziv u Druga državna klasična gimnazija u Zagrebu. ${ }^{21}$ Koloman Rac zbog godina provedenih u službi napreduje, tako da krajem 1902. prelazi u VIII. činovnički razred, prvo niži, a 1905. viši, dok 1909. prelazi u VII. činovnički razred. Dekretom od 21. rujna 1916. na vlastitu je molbu umirovljen u dobi od 53 godine, a rješenjem od 16. listopada 1916. odlazi u mirovinu te je odlikovan naslovom srednjoškolskog ravnatelja. Dvije godine kasnije na vlastitu se molbu ponovo vraća na posao te je u listopadu 1918. pozvan u privremenu službu kao učitelj, međutim ne u Kraljevsku II. veliku gimnaziju gdje je prije radio, nego u Kraljevsku I. realnu gimnaziju. 30. siječnja 1919. proglašen je redovnim srednjoškolskim profesorom VII. činovničkog razreda, a 17. travnja iste godine unaprijeđen je u VI. činovnički razred. Dekretom od 24. siječnja 1922. imenovan je ravnateljem Kraljevske II. velike gimnazije u Zagrebu i u službu nastupa 1. veljače 1922. Svoj radni vijek završava 1925. kad je kraljevskim ukazom kralja Aleksandra Karađorđevića od 18. siječnja umirovljen u dobi od 61 godine s 38 godina staža.

U spomenutoj knjizi Matica i sposobnik za učitelje $e^{22}$ pobrojani su i njegovi radovi, nešto opsežnije nego što je to navedeno u natuknici on-line izdanja Hrvatske enciklopedije ${ }^{23}$. Matica Hrvatska objavila je i nagradila njegov prijevod Sofoklovih

19 HR-DAZG-24 Gradsko poglavarstvo Zagreb, Opće skupno groblje grada Zagreba na Mirogoju, MIR 42 Grobne knjige groblja Mirogoj, I. razred, grobno polje 11A, br. groba 131.

20 HR-DAZG-10 Gradsko poglavarstvo Zagreb, Zdravstveni odsjek, ZO 189, Mrtvozornički registar za 1937., I. kotar, br. 31.

21 Vodič kroz fondove i zbirke Državnog arhiva u Zagrebu, Državni arhiv u Zagrebu, Zagreb 2008., I. sv., str. 325-326.

22 HR-DAZG-103 II. klasična gimnazija u Zagrebu, br. 25270, Matica i sposobnik za učitelje.

23 Enciklopedijski članak: Rac, Koloman, on-line izdanje Hrvatske enciklopedije Leksikografskog zavoda Miroslav Krleža. www.enciklopedija.hr/natuknica.aspx?id=51361 (podaci preuzeti u studenom 2016.). 
drama u prozi 1895., prijevod Cezarovog Galskog i Građanskog rata 1897., a 1902. njegovu knjigu Život starih Grka kojom je pridonio popularizaciji klasične filologije u Hrvatskoj. Napisao je uvod i bilješke za prijevod Vergilijeve Eneide Tomislava Maretića, koji je Matica Hrvatska objavila 1896. Priredio je drugo izdanje Primjera iz rimske književnosti Stjepana Senca, koje je objavljeno u Zagrebu 1909. i 1910. Zajedno sa Stjepanom Srkuljem priredio je čitanku za osmi gimnazijski razred Monumenta historiam Croaticam spectantia, koja u prvome dijelu sadrži epigrafski materijal iz naših priobalnih gradova, a u drugom 17 najznačajnijih isprava iz hrvatske povijesti od 852. do 1722., a objavljena je 1909. Sljedeće godine objavljen je izbor iz djela grčkog povjesničara Ksenofonta, a 1913. novi prijevod Sofokolovih tragedija, ovaj put u stihovima, koji ponovno objavljuje Matica Hrvatska. 1915. Matica Hrvatska objavljuje dva izdanja njegovih prijevoda Platonovih djela - u jednoj su knjizi Apologija i Fedon, a u drugoj Protagora. Sljedeće godine Matica Hrvatska objavljuje Antologiju lirike grčke. Zajedno s Franjom Lasmanom priredio je Izbor iz stare književnosti kršćanske koji je objavljen 1917. Zatim se vraća rimskoj književnosti, pa je priredio Izbor iz Ovidijevih djela objavljen u Zagrebu 1919. Matica Hrvatska 1920. i 1921. objavljuje njegove prijevode Eshilovih tragedija i Euripidovih drama u dvije knjige. Radio je i prijevode grčkog komediografa Aristofana i rimskog komediografa Plauta za "Mladost“, list za zabavu i pouku srednjoškolske mladeži koji je izlazio u Zagrebu. Za svoj je rad odlikovan Redom sv. Save IV. stupnja poveljom od 19. listopada $1921 .{ }^{24}$

Koloman Rac umro je u Zagrebu 23. siječnja 1937. u 4 sata ujutro zbog zatajenja srca sa 73 godine, a pokopan je dva dana kasnije na Mirogoju u obiteljskoj grobnici. ${ }^{25}$ Iako mu je zadnji veliki prijevod objavljen 1921., to ne znači da nije i dalje prevodio. Prepjevao je osam Plautovih komedija koje su posmrtno objavljene 1951. i 1959. i Plutarhove Usporedne životopise. Njegovi su prijevodi doživjeli još mnoga ponovljena izdanja te se i danas koriste u školskoj lektiri.

Ovime nisu iscrpljeni svi arhivski dokumenti o Kolomanu Racu. Prostora za daljnje istraživanje ima u arhivu Filozofskog fakulteta gdje bi se mogli naći dokumenti o njegovim studentskim danima. Fond Zemaljske vlade, Odjela za bogoštovlje i nastavu (HR-HDA-80) u Hrvatskom državnom arhivu zasigurno sadrži spise o izdavanju njegovih prijevoda i djela, a možda bi se moglo doznati više o njegovom prvom umirovljenju i povratku na posao. Budući da je Matica Hrvatska također bila izdavač njegovih radova, podaci o njegovom djelovanju mogli bi se naći i u fondu HR-HDA-1567 Matica Hrvatska. U Državnom arhivu u Zagrebu sačuvano

\footnotetext{
${ }^{24}$ HR-DAZG-103 II. klasična gimnazija u Zagrebu, br. 25270, Matica i sposobnik za učitelje.

25 HR-DAZG-10 Gradsko poglavarstvo Zagreb, Zdravstveni odsjek, ZO 189, Mrtvozornički registar za 1937., I. kotar, br. 31.
} 


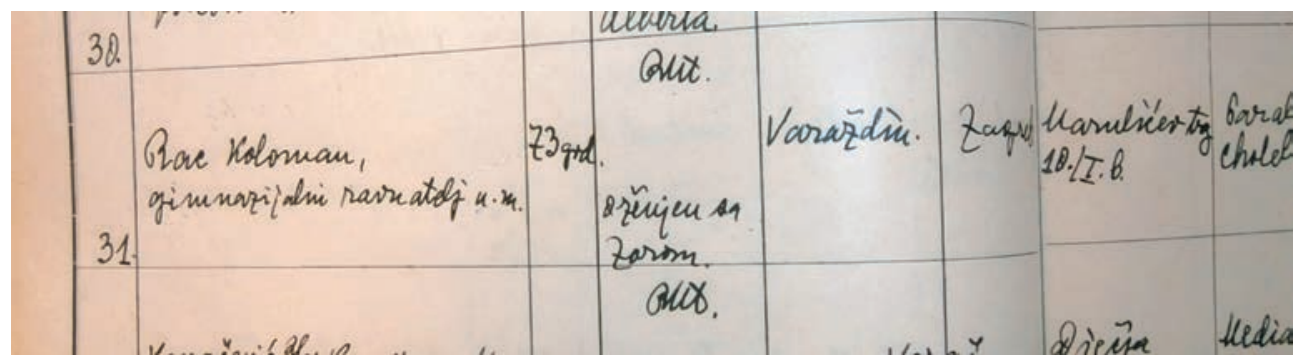

Slika 9. HR-DAZG-10 Gradsko poglavarstvo Zagreb, Zdravstveni odsjek, ZO 189, Mrtvozornički registar za 1937., I. kotar, br. 31.

je gradivo I. realne gimnazije u Zagrebu (HR-DAZG-109), gdje je Koloman kao profesor proveo nekoliko godina. U konačnici, njegova supruga Zora koja je u šest godina rodila petoro djece i brinula se za cijelo kućanstvo tako da njezin suprug može u miru prevoditi, također zaslužuje da se o njoj više dozna.

Na kraju se najljepše se zahvaljujem kolegicama arhivisticama Katarini Horvat iz Državnog arhiva u Zagrebu, Mariji Fajdić iz Državnog arhiva u Gospiću i Mirjani Hurem iz Hrvatskog državnog arhiva na njihovom trudu i pomoći.

\section{IZVORI}

\section{Hrvatski državni arhiv (HDA)}

1. HR-HDA-502 Ispitna komisija za polaganje stručnih ispita za zvanje profesora srednjih škola Filozofskog fakulteta u Zagrebu, 3 Materijali s ispita - dosje Kolomana Raca.

\section{Državni arhiv u Gospiću (DAGS)}

1. HR-DAGS-109 Zbirka matičnih knjiga, Matična knjiga rođenih Gospić 1887.-1894.

2. HR-DAGS-117 Gimnazija Nikola Tesla Gospić, Glavni imenik 1889/90. i Zapisnik ob izpitih zrelosti 1887/88. - 1890/91.

3. Državni arhiv u Varaždinu (DAVŽ).

4. HR-DAVŽ-249 Gimnazija Varaždin, Glavni katalozi 1774/75.-1881/82. i Zapisnici ispita zrelosti 1866/67.-1885/86.

5. HR-DAVŽ-543 Matične knjige rimokatoličkih župa, Župa sv. Nikole u Varaždinu, Matična knjiga rođenih 1858-1868. i Matična knjiga vjenčanih 1878.-1898.

6. HR-DAVŽ-543 Matične knjige rimokatoličkih župa, Župa sv. Vida u Varaždinu, Matična knjiga rođenih 1860.-1877. 


\section{Državni arhiv u Zagrebu (DAZG)}

1. HR-DAZG-10 Gradsko poglavarstvo Zagreb, Zdravstveni odsjek ZO 189, Mrtvozornički registar 1937.

2. HR-DAZG-24 Gradsko poglavarstvo Zagreb, Politički odsjek, POLIT4, Imenik zavičajnika grada Zagreba.

3. HR-DAZG-24 Gradsko poglavarstvo Zagreb, Opće skupno groblje grada Zagreba na Mirogoju, MIR 42, Grobne knjige groblja Mirogoj.

4. HR-DAZG-103 II. klasična gimnazija u Zagrebu, br. 25270, Matica i sposobnik za učitelje.

\section{Gradski muzej Varaždin (GMV)}

1. Katastarski plan grada Varaždina, Antun Kiesswetter, 1860.g., inv. br. 3392.

2. Fotografija obiteljske grobnice obitelji Rac preuzeta s https://billiongraves.com/ grave/Koloman-Rac/18203563\#/ (srpanj 2017.).

3. Tražilica pokojnika Gradskih groblja Zagreb http://www.gradskagroblja.hr/ default.aspx?id=382 (srpanj 2017.).

\section{BIBLIOGRAFIJA}

1. „Rac, Koloman“, on-line izdanje Hrvatske enciklopedije Leksikografskog zavoda Miroslav Krleža. www.enciklopedija.hr/natuknica.aspx?id=51361 (podaci preuzeti u studenom 2016.).

2. Vida PAVLIČEK: „Varaždinske gradske zaklade krajem 19. i početkom 20. stoljeća", Hrvatska akademija znanosti i umjetnosti, Radovi Zavoda za znanstveni rad Varaždin, 6-7/1994, 123. - 145.

3. Ljubica RADOVIĆ: "Zaklade, potpore i donacije gimnaziji Varaždinskoj", Hrvatska akademija znanosti i umjetnosti, Radovi Zavoda za znanstveni rad Varaždin, 10-11/1998, 157. - 180.

4. Vodič kroz fondove i zbirke Državnog arhiva u Zagrebu, Državni arhiv u Zagrebu, Zagreb 2008., I. sv. 


\section{SAŽETAK}

\section{KOLOMAN RAC U ARHIVSKIM DOKUMENTIMA}

Koloman Rac rođen je u Varaždinu 19. rujna 1863., pohađao je varaždinsku Gimnaziju od 1874. do 1882. i oženio se Zorom Kraljek 1887., o čemu svjedoče arhivski dokumenti iz Državnog arhiva u Varaždinu (Matice rođenih i vjenčanih te Glavni katalozi i Zapisnici ispita zrelosti varaždinske Gimnazije). Najvažnije gradivo za biografiju Kolomana Raca čuva se u Državnom arhivu u Zagrebu u fondu HR-DAZG-103 II. klasična gimnazija u Zagrebu, u sklopu kojega se nalazi knjiga Matica i sposobnik za učitelje s najpotpunijim podacima o njegovom školovanju, svim radnim mjestima te objavljenim prijevodima i djelima. Gradivo Državnog arhiva u Gospiću vrlo malo govori o radu Kolomana Raca, međutim, podaci iz matične knjige rođenih 1887.-1894. omogućuju upoznavanje njegovog obiteljskog života jer mu se u Gospiću rodilo četvero djece. Pored spomenute matice, podaci o životu Kolomana Raca u Zagrebu, gdje je proveo većinu života, sadržani su u fondovima Gradskoga poglavarstva Zagreb (fondovi 10 i 24) u Državnom arhivu u Zagrebu. U Imeniku zavičajnika grada Zagreba upisana je njegova obitelj s petim djetetom, dok Mrtvozornički registar i Grobne knjige groblja Mirogoj donose podatke o njegovoj smrti 23. siječnja 1937.

Ključne riječi: Koloman Rac; arhivski dokumenti; biografija.

\section{SUMMARY}

\section{KOLOMAN RAC IN ARCHIVAL DOCUMENTS}

Koloman Rac was born in Varaždin on September 19, 1863. He attended the Varazdin Gymnasium from 1874 to 1882 and married Zora Kraljek in 1887, as evidenced by the archival records from the State Archives in Varazdin (Registers of births and marriages and Main catalogues and Minutes of matriculation exams of Varazdin Gymnasium). The most important records for the biography of Koloman Rac are preserved in the State Archives in Zagreb. The book The register of teachers is particularly noteworthy. It belongs to the fonds HR-DAZG-103 II. Classical Gymnasium in Zagreb and it lists the data about his education, all of his workplaces and published translations and books he wrote. The records in the State Archives in Gospic reveal very little about the work of Koloman Rac, however, the data from the register of birth 1887-1894 allow exploring his family life because four of his children were born in Gospic. Besides the mentioned Register of teachers, data on life of Koloman Rac in Zagreb, where he spent most of his life, are contained in the funds of the City Council of Zagreb (funds 10 and 24) at the State Archives in Zagreb. His family is registered in the Directory of residents of the city of Zagreb and his fifth child is mentioned there, while the Coroner register and Grave book of Mirogoj cemetery contain information about his death on January 23, 1937.

Key Words: Koloman Rac; archival documents; biography. 